Technological University Dublin

DÜBLIN

ARROW@TU Dublin

\title{
Influence of Magnesium Nitrate on the Corrosion Performance of Sol-Gel Coated AA2024-T3 Aluminium Alloy
}

\author{
Rajath Varma \\ Technological University Dublin, rajath.varma@tudublin.ie \\ Brendan Duffy \\ Technological University Dublin, brendan.duffy@tudublin.ie \\ John Cassidy \\ Technological University Dublin, john.cassidy@tudublin.ie
}

Follow this and additional works at: https://arrow.tudublin.ie/cenresart

Part of the Ceramic Materials Commons, Inorganic Chemistry Commons, Materials Chemistry Commons, Nanoscience and Nanotechnology Commons, and the Polymer Chemistry Commons

\section{Recommended Citation \\ Varma, R., Duffy, B., Cassidy, J. (2009) : Influence of Magnesium Nitrate on the Corrosion Performance of Sol-Gel Coated AA2024-T3 Aluminium Alloy. Surface \& Coatings Technology, Vol. 204 (2009) pp.277-284. doi:10.1016/j.surfcoat.2009.07.024}

This Article is brought to you for free and open access by the Crest: Centre for Research in Engineering Surface Technology at ARROW@TU Dublin. It has been accepted for inclusion in Articles by an authorized administrator of ARROW@TU Dublin. For more information, please contact arrow.admin@tudublin.ie, aisling.coyne@tudublin.ie,gerard.connolly@tudublin.ie. Funder: Enterprise Ireland

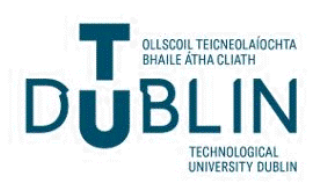




\section{Manuscript}

Click here to view linked References

Influence of magnesium nitrate on the corrosion performance of sol-gel coated AA2024-T3 aluminium alloy

\section{P.C. Rajath Varma ${ }^{\mathrm{a}, \mathrm{b}}$, Brendan Duffy ${ }^{\mathrm{a}}$, John Cassidy ${ }^{\mathrm{b}}$}

${ }^{a}$ Centre for Research in Engineering Surface Technology (CREST), FOCAS Institute, Dublin Institute of Technology, Kevin St., Dublin 8, Ireland.

${ }^{b}$ School of Chemical and Pharmaceutical Sciences, Dublin Institute of Technology, Kevin St., Dublin 8, Ireland.

\section{Abstract}

Traditional anti-corrosion technology has relied heavily on using reducible metal species, predominantly hexavalent chromium $(\mathrm{Cr}(\mathrm{VI}))$, for protecting reactive metal alloys such as aluminium which is extensively used in the aerospace sector. However, the impending changes in the use of $\mathrm{Cr}(\mathrm{VI})$ in Europe and the United States have forced aerospace manufacturers to examine alternative materials for protecting aluminium. One of the most promising alternatives being investigated are organosilane based sol-gels containing anticorrosion additives. In this work the anti-corrosion properties of magnesium (II) nitrate $\left(\mathrm{Mg}\left(\mathrm{NO}_{3}\right)_{2}\right)$ as a inhibitor was investigated at different concentrations $(0.1 \%-1.0 \mathrm{wt} \%)$ in a methyltriethoxysilane (MTEOS) sol-gel on the aluminium alloy AA 2024-T3 and compared to Alodine ${ }^{\mathrm{TM}}$ 1200 (the established $\mathrm{Cr}(\mathrm{VI})$ pre-treatment). Electrochemical evaluation of the coating system by electrochemical impedance spectroscopy (EIS) and potentiodynamic scanning (PDS) measurements correlated strongly with results obtained from Neutral Salt Spray (NSS) exposure data. The surface morphology of the coating was studied using atomic force microscopy (AFM) and scanning electron microscopy (SEM). The results indicated the optimum performance was achieved using a $\mathrm{Mg}\left(\mathrm{NO}_{3}\right)_{2}$. level of $0.7 \% \mathrm{w} / \mathrm{w}$. It is proposed that the superior anticorrosion properties of the $\mathrm{Mg}^{2+}$ rich sol-gel is due to the pore blocking mechanism of insoluble $\mathrm{Mg}(\mathrm{OH})_{2}$ formed during the hydrolysis process.

Keywords: Corrosion; Sol-Gel; Magnesium Nitrate; Corrosion Inhibition; Aluminium Alloy

Corresponding author. Tel.: +35314027964; fax: +35314027941.

E-mail address: bduffy@dit.ie (Brendan Duffy) 


\section{Introduction}

Conventional hexavalent chromium (Cr (VI)) based pre-treatments have historically played an important role in aircraft, marine, automotive and building industries by providing excellent corrosion protection on engineered surfaces [1]. The remarkable ability of hexavalent chromium as a corrosion inhibitor is due to it's stability on reduction to trivalent chromium. However the active ingredient, $\mathrm{Cr}(\mathrm{VI})$, is known to be toxic and poses serious human health and environmental hazards. Rigid environmental regulations, introduced in the US and EU, have mandated the elimination of hexavalent chromium as the active ingredient in corrosion inhibition [2,3]. Initially reducible metal salts of vanadium, cerium and molybdenum were considered as alternative inorganic inhibitors as within organic coatings and surface pre-treatments, as were phosphates and borates $[4,5]$.

More recently inorganic-organic polymers based on sol-gel technology materials have been investigated for protecting aluminium alloys, specifically those used in the aerospace industry [4]. A sol-gel is formed by a combination of hydrolysis and condensation reactions, followed by polymerization and gelation of metal oxides from a colloidal solution [6]. Sol-gel technology offers a variety of routes to prepare functional coatings with different properties while those based on silane chemistry possess excellent adhesion to both metallic substrates and organic top coats through covalently formed bonds [7, 8]. By controlling the organic component within the sol-gel, improvements in properties such as flexibility and hydrophobicity can be achieved [9]. As with all coatings, silane based sol-gel films can only offer adequate long term protection in the absence of micro pores and cracks. In the event of cracks or defects developing the inclusion of environmentally compliant corrosion inhibitors into the sol-gel coatings is necessary to maintain their protective capability by suppressing the corrosion process at such defects [10]. A US Air Force study investigated three environmentally compliant reducible metal salts (cerium nitrate, sodium vanadate and sodium molybdate) as corrosion inhibitors within epoxysilane-zirconia sol-gel coatings on AA2024-T3 [11]. It was found that only the cerium salts maintained or improved the barrier properties of the coatings. Subsequent studies investigating the long term stability of such cerium coatings 
identified solubility and leaching issues $[10,12,13,14]$. These issues were solved by modifying the cerium salts prior to addition into sol gel thus delivering coatings with excellent corrosion resistance [15]. Improved corrosion performance can also be achieved by physically preventing electrolyte reaching a metal surface, by blocking the coating pores with insoluble metal hydroxide precipitates. This technique has been exploited with zinc-rich primers on metal surfaces whereby the formation of corrosion product precipitates inside a coating, occur around zinc particles, blocking the pores thereby increasing its barrier resistance [16]. Recently increased attention, particularly from North Dakota State University, has focused on magnesium as a corrosion inhibitor in epoxy primers and some sol-gels for protecting aerospace alloys $[17,18,19,20]$. The researchers have found that magnesium can provide sacrificial protection and also form a protective oxide layer at the alloy surface thereby enhancing barrier protection.

In this body of work the anticorrosion properties of magnesium nitrate $\left(\mathrm{Mg}\left(\mathrm{NO}_{3}\right)_{2}\right)$ doped sol-gels were investigated on the aluminium alloy AA2024-T3. Classical electrochemical techniques, namely electrochemical impedance spectroscopy and potentiodynamic scanning, were used to estimate optimum concentration levels for corrosion protection, while accelerated exposure data was obtained from Neutral Salt Spray. The surface morphology of the coating structures was investigated by atomic force and scanning electron microscopy. The coating performance was compared to the established hexavalent chromium Alodine ${ }^{\mathrm{TM}} 1200$ based systems. The data shows that optimum levels of $\mathrm{Mg}\left(\mathrm{NO}_{3}\right)_{2}$ improves the corrosion performance of the sol-gel significantly through a proposed pore-blocking mechanism, due to the formation of insoluble magnesium hydroxide.

\section{Experimental}

\subsection{Aluminium Panel Preparation}

$150 \mathrm{~mm}$ x $100 \mathrm{~mm}$ AA2024-T3 aluminium panels (sourced from an industrial partner) were washed with isopropanol, degreased and cleaned using Oakite $61 \mathrm{~B}^{\circledR}$ before being finally rinsed with deionised water and dried. 


\subsection{Alodine Treatment}

An Alodine ${ }^{\mathrm{TM}} 1200$ solution was prepared by dissolving Alodine ${ }^{\mathrm{TM}} 1200$ powder (2\%) in deionised water and maintaining the $\mathrm{pH} \approx 2$ by adding conc. $\mathrm{HNO}_{3}$. The Alodine ${ }^{\mathrm{TM}}$ solution was left stirring for overnight and then filtered into a glass container. The cleaned AA 2024-T3 panels where then immersed in the chromium solution for 1 minute. The panels were then cleaned with deionised water and left to dry at ambient temperature.

\subsection{Sol-Gel Preparation}

The silane sols were prepared by hydrolysing the silane precursor methyltrimethoxysilane (MTEOS) in the presence of dilute $\mathrm{HNO}_{3}$ (aq) as a catalyst, with ethanol (EtOH) as a solvent with a molar ratio of 1/0.001/2.5/5 (MTEOS/HNO $\left./ \mathrm{ETOH}_{3} \mathrm{H}_{2} \mathrm{O}\right)$ to give an overall volume of $100 \mathrm{~mL}$. The precursor MTEOS (99\%) was sourced from Aldrich was used without any further purification. The solution was stirred initially for an hour. From this stock solution $10 \mathrm{~mL}$ volumes were prepared with varying levels of magnesium nitrate $\left(\mathrm{Mg}\left(\mathrm{NO}_{3}\right)_{2}\right.$, Aldrich) to give sols of $0.1,0.3,0.5,0.7$ and $1.0 \% \mathrm{w} / \mathrm{w}$ when measured against the dried film weight. All the reaction mixtures were stirred overnight to complete the reaction. The prepared AA2024-T3 panels were flood coated with the sol, before being spun coat at up to $1000 \mathrm{rpm}$ and cured for $12 \mathrm{hrs}$ at $100^{\circ} \mathrm{C}$ to form the gel. The controlled coating technique gave a final thickness of $1.5 \mu \mathrm{m}( \pm 0.5 \mu \mathrm{m})$ for all sol-gel coatings, measured using Isoscope ${ }^{\circledR}$ non destructive coating thickness gauge. Shorthand notation for the coatings will rely on the level of magnesium, i.e. $0.5 \% \mathrm{Mg}$ will be used to represent MTEOS $+0.5 \% \mathrm{Mg}\left(\mathrm{NO}_{3}\right)_{2}$.

\subsection{Coating Characterisation}

EIS and PDS data was obtained using a Solartron SI 1287/1255B system comprising of a frequency analyser, potentiostat and ZPlot ${ }^{\circledR}$ software. Harrison's solution $\left(3.5\right.$ wt \% $\left(\mathrm{NH}_{4}\right)_{2} \mathrm{SO}_{4}$ and $\left.0.5 \% \mathrm{NaCl}\right)$ was used as electrolyte as it closely emulates the atmospheric environment for aircraft [21]. EIS electrochemical cells were made by mounting bottom-less plastic vials to the exposed surface of the 
coated panel $\left(4.9 \mathrm{~cm}^{2}\right)$ with amine hardened epoxy glue (Araldite $\left.{ }^{\circledR}\right)$. EIS spectra were acquired in the frequency range from $10^{6} \mathrm{~Hz}$ to $10^{-1} \mathrm{~Hz}$ with modulating potential of $10 \mathrm{mV}$ around the rest potential. The coated metal thus acted as a working electrode, silver/silver chloride $(\mathrm{Ag} / \mathrm{AgCl})$ electrode was used as a reference electrode and platinum mesh acted as a counter electrode.

PDS was performed using an electrochemical cell (PAR EG\&G K0235 Flat Cell). Constant air supply was given to the system in order to promote the corrosion process. An initial free corrosion potential $\left(E_{\mathrm{oc}}\right)$ measurement was recorded using an open circuit potential (OCP) technique and the potentiodynamic scan was acquired in the region from $-0.4 \mathrm{~V}$ to $+0.5 \mathrm{~V}$ vs. $E_{\mathrm{oc}}$, with a scan rate of $1 \mathrm{mV} / \mathrm{sec}$. The area exposed was $0.78 \mathrm{~cm}^{2}$ to Harrison's solution. All the experiments were repeated in duplicate.

\subsection{Salt Spray Exposure}

Accelerated exposure testing of all panels was performed in a salt fog atmosphere generated from a $5 \mathrm{wt}$ $\%$ aqueous $\mathrm{NaCl}$ solution at $35( \pm 1){ }^{\circ} \mathrm{C}$ for up to $168 \mathrm{hrs}$ according to ASTM B117 specifications. Solgel coated panels of size 4" x 3" were used for the exposure test. The non coated side and the edges were protected using water a based polyurethane coating (Alberdink ${ }^{\circledR}$ ). The edges were further protected with insulation tapes to provide a double protection.

\subsection{Surface morphology}

Surface morphology of the coating was studied using atomic force (AFM) and scanning electron microscopy (SEM). AFM studies were undertaken using an Asylum MFP-3D AC/contact mode microscope. Damage to tip and sample surface were minimized by employing the experiment in tapping mode as it is specifically useful for soft samples such as polymers and biological samples. The tapping mode works by reducing the vibration amplitude of the cantilever thereby acting as the feedback signal. SEM studies were completed using a Tescan Mira XMU system, with electron beam energy of $20 \mathrm{keV}$ and a magnification of up to $20 \mathrm{Kx}$. The coated sample were mounted on copper stud and coated with gold with a thickness of $\sim 50 \mathrm{~nm}$, to make the sample conducting. 


\section{Result and Discussion}

\subsection{Electrochemical Impedance spectroscopy}

EIS is a technique that can simultaneously provide information on the corrosion mechanism and quantitatively assess the corrosion protection provided by a metal substrate. It allows for physical systems to be expressed as equivalent electrical systems such as resistors and capacitors and has been discussed elsewhere [4]. The EIS spectrum is frequency dependant and is dominated by the properties of the electrolyte $\left(>\sim 10^{5} \mathrm{~Hz}\right)$, coating $\left(\sim 10^{0}-10^{5} \mathrm{~Hz}\right)$ and surface interactions $\left(<\sim 10^{0} \mathrm{~Hz}\right)$. Effective barrier coatings display impedance values of at least $10^{6} \Omega \cdot \mathrm{cm}^{2}$ at lower frequencies $\left(\leq 10^{-1} \mathrm{~Hz}\right)$, implying low rates of electrochemical activity and hence lower corrosion rates [22]. A summary of impedance data for all sol-gel coatings recorded at $10^{-1} \mathrm{~Hz}$ is shown in Fig. 1 .

\section{Fig 1}

The most important aspect of this data is the trend observed, where the low frequency impedance is dependent on the coating and immersion time [23]. It is clear that only the mid range concentrations $(0.5 \%$ $\& 0.7 \% \mathrm{Mg}$ ) maintain their barrier properties over the 72 hour period. Moreover it should be noted that the higher and lower concentrations $(0.1 \% \& 1.0 \% \mathrm{Mg})$ performed poorly, as represented by a decrease in their impedance by 2.5 and 1.8 orders of magnitude respectively. The result for $1 \% \mathrm{Mg}$ is in agreement with electrochemical impedance result from literature, which indicates that sol-gel coatings heavily loaded with inorganic particles can become porous, thereby increasing uptake of water leading to coating delamination [24].

The corresponding Bode frequency plots at 0 and 72 hours is shown in Fig. 2 (a) \& (b). At 0 hours there is one time constant, extending across the mid frequency range, which is indicative of a barrier coating. This is to be expected with all coatings as the electrolyte has had minimal interaction with the coating and will not have reached the surface. After 72 hours a second time constant has emerged for all coatings in the 
low frequency region, indicating the formation of a surface phenomenon. This may be an aluminium corrosion product, magnesium rich precipitate or a combination of both.

\section{Fig 2 (a) \& (b)}

Similar phenomena reported in the literature have been ascribed to an intermediate oxide layer formed on alloy/sol-gel coating interface by Si-O-Al bonds, respectively [25]. The data indicates that the $0.5 \%$ and $0.7 \% \mathrm{Mg}$ systems maintain high phase angle $\left(\approx 80^{\circ}\right)$ over the mid frequency range, implying superior barrier properties when compared to the other coatings.

\section{Fig 3 (a) \& (b)}

The electrochemical circuit models shown in Figure 3 correlates the physical characteristics of the coating with the impedance spectrum. The theory of equivalent circuit has long been established and extensive work has been published [26, 27]. Here the circuit model illustrated at Figure 3 (a) describes the behaviour of the sol gel coating during the initial stages of immersion while Figure 3 (b) describes the behaviour of the system from $24 \mathrm{hrs}$ to $72 \mathrm{hrs}$ after immersion. The constant phase element (CPE) was used as capacitance in all fittings when the phase angle of the capacitor is different from $-90^{\circ}$. The parameter $\mathrm{R}_{\text {sol }}$ corresponds to the solution resistance, $\mathrm{R}_{\text {coat }}$ is the coating resistance, $\mathrm{C}_{\text {coat }}$ is the coating capacitance, $\mathrm{R}_{\text {int }}$ is the resistance at coating/alloy interface and $\mathrm{C}_{d l}$ accounts for the double layer capacitance. The evolution of $\mathrm{C}_{\text {coat }}$ is related to the penetration of electrolyte through the coating and generally is expected to increase with exposure time and coating degradation [28]. The fitting parameters are illustrated in Table 1.

\section{Fig 4 (a) \& (b)}

Fig 4 (a) displays the evolution of $\mathrm{C}_{\text {coat }}$ with the immersion time in Harrison's solution. It was observed that the capacitance values of the coatings with magnesium were lower than that of the $0 \% \mathrm{Mg}$ coating which provides limited corrosion protection and is indicative of more hydrophobic coating. The increase in $C_{\text {coat }}$ for the $0.1 \% \mathrm{Mg}$ coating is believed to be due to insufficient levels of inhibitor within the sol gel matrix to prevent corrosion. Significant improvement in corrosion properties were found for $0.3 \% \mathrm{Mg}$ and 
$0.5 \% \mathrm{Mg}$ coating with a slight increase in $C_{\text {coat }}$, while $0.7 \% \mathrm{Mg}$ showed the lowest increase, implying that it was the most capable coating for retarding the passage of electrolyte through the coating. It is proposed that the increase in $C_{\text {coat }}$ for $1 \% \mathrm{Mg}$ was due to heavily loaded inorganic particles in sol-gel matrix forming porous pathways for the electrolyte to the metal surface [24].

The change in coating resistance $\left(\mathrm{R}_{\text {coat }}\right)$ during immersion in the Harrison's solution which combines the resistance of electrolyte in pores and cracks in the coating [10] is presented in Fig 4(b). The undoped coating has the lowest coating resistance throughout the entire period of immersion when compared to coating containing the $\mathrm{Mg}\left(\mathrm{NO}_{3}\right)_{2}$. The initial value of $\mathrm{R}_{\text {coat }}$ of the inhibitor doped coatings is higher for all concentration except for $0.7 \% \mathrm{Mg}$. However, by increasing the immersion time to $72 \mathrm{hrs}, 0.7 \% \mathrm{Mg}$ showed a consistent behaviour in coating performance most likely due to blocking of the pores. In contrast all the other sol gel coatings undergo a decrease in coating resistance with immersion time.

\section{Table 1}

In the event of chloride promoted corrosion on AA2024-T3 alloys hydroxyl ions are generated via oxygen reduction (1) at cathodic sites, such as those formed upon dealloying of secondary phase (S-phase) intermetallic compositions such as $\mathrm{Al}_{2} \mathrm{CuMg} .[29,30,31]$.

Cathodic reaction:

$\mathrm{O}_{2}+2 \mathrm{H}^{+}+4 e^{-} \longrightarrow 2 \mathrm{OH}^{-}$

When these hydroxyl ions interact with the magnesium salts within the sol-gel, it is proposed that insoluble magnesium hydroxide $\left(\mathrm{Mg}(\mathrm{OH})_{2} \mathrm{~K}_{\mathrm{sp}}\right.$ of $\left.1.5 \times 10^{-11}\right)$ is formed thereby blocking the coating pores (2). This is represented by a stable high impedance at lower frequencies in the Bode plot in Fig. 2(b), indicative of the capacitive nature displayed by the coating.

$$
\mathrm{Mg}^{2+}+2 \mathrm{OH}^{-} \longrightarrow \mathrm{Mg}(\mathrm{OH})_{2}
$$

\subsection{Potentiodynamic Scanning}

To estimate the effect of the $\mathrm{Mg}\left(\mathrm{NO}_{3}\right)_{2}$ on the anodic and cathodic electrode reactions, potentiodynamic scan were carried out in the potential range from $-0.4 \mathrm{~V}$ to $0.5 \mathrm{~V}$ versus the $\mathrm{OCP}$. The corrosion parameters such as corrosion current densities $\left(I_{\text {corr }}\right)$ and corrosion potential $\left(E_{\text {corr }}\right)$ were estimated by the Tafel 
method within the range OCP $\pm 1 \mathrm{mV}$ [32]. The polarisation resistance is calculated using Stern-Geary equation [33] (3)

$$
I_{\text {corr }}=\frac{B}{R_{p o l}}
$$

Where $\mathrm{R}_{\mathrm{pol}}$ is the polarisation resistance. The proportionality constant, $\mathrm{B}$, for a particular system can be calculated from $\beta_{\mathrm{a}}$ and $\beta_{\mathrm{c}}$, the slopes of the anodic and cathodic Tafel lines as shown by (4).

$$
B=\frac{\beta_{a} . \beta_{c}}{2.303\left(\beta_{a}+\beta_{c}\right)}
$$

\section{Fig 5}

The polarization curves for all sol-gel coatings are shown in Fig. 5 with the extracted physical properties shown in Table 2. The effect of magnesium content is clearly evident with the lowest $\mathrm{I}_{\text {corr }}$ readings being achieved by $0.7 \% \mathrm{Mg}$ and $0.5 \% \mathrm{Mg}$ respectively, which are up to 5 orders lower in magnitude when compared to the sol-gel alone. This confirms that some of the magnesium laden coatings are capable of blocking the ingress of electrolyte to the active reaction sites on the aluminium alloy (both anodic and cathodic sites) [34]. The polarization curves (Fig 5) for $0.5 \%$ and $0.7 \% \mathrm{Mg}$ demonstrate well defined passivation regions that are indicative of the retained inhibition activities of incorporated compounds with high polarization resistances from $4.3 \times 10^{9} \Omega . \mathrm{cm}^{2}$ to $1.7 \times 10^{9} \Omega . \mathrm{cm}^{2}$ respectively. Coatings with high $\mathrm{R}_{\mathrm{pol}}$ are desirable for achieving low corrosion rates [35]. The polarization curve for $1 \% \mathrm{Mg}$ shows no anodic or cathodic protection as there is a decrease in coating properties $\left(\mathrm{I}_{\mathrm{corr}}=2.1 \times 10^{-8} \mathrm{~A} . \mathrm{cm}^{-1}, R_{p o l}=2.6\right.$ $\mathrm{x} 10^{5} \Omega \cdot \mathrm{cm}^{2}$ ). This is due to the instability of the sol gel network with an increase in concentration of inorganic particles and is agreement with literature reports [24].

\section{Table 2}

\subsection{Comparison between optimised sol-gel system and traditional Alodine ${ }^{\mathrm{TM}} 1200$}

To establish the potential benefit of the magnesium rich sol-gel system, a comparison was made with both bare and Alodine ${ }^{\mathrm{TM}} 1200$ treated AA2024-T3 panels. EIS data is not presented for the hexavalent chromium rich Alodine $\mathrm{TM}^{\mathrm{TM}} 200$ treated panel as it has minimal barrier properties as it is significantly 
thinner $(0.2 \mu \mathrm{m})$ than that of the sol-gel coatings $(1.5 \mu \mathrm{m})$. The potentiodynamic scan shown in Fig. 6 illustrates the improved benefit of magnesium rich coatings in comparison to the Alodine ${ }^{\mathrm{TM}} 1200$ system. All sol-gel coatings containing magnesium, with the exception of $1 \% \mathrm{Mg}$, display lower current densities than the Alodine ${ }^{\mathrm{TM}}$ equivalent.

\section{Fig 6}

Table 2

\subsection{Neutral Salt Spray results (NSS)}

The results from neutral salt spray exposure for the sol-gels, Alodine ${ }^{\mathrm{TM}}$ and bare panels is shown in Fig. 7. Failure of a coating was defined as being three or more pits per panel (adapted from the BS EN ISO10289 standard) or coating delamination. Panels were inspected at $24 \mathrm{hr}$ intervals. Upon failure panels were removed. After 24 hours significant corrosion product was noted on the blank panel and it was removed from the chamber. $0 \% \mathrm{Mg}$ failed between 96 and 120 hours. All other panels were removed after completion of 168 hours testing. Only $0.7 \% \mathrm{Mg}$ survived with no visible pitting, while $0.5 \% \mathrm{Mg}$ failed with 3 pits. Alodine ${ }^{\mathrm{TM}} 1200$ pre treatment failed with general corrosion observed after 96 hours which is significant for a thin $(<200 \mathrm{~nm})$ coatings.

\section{Fig 7}

\subsection{Morphological Analysis}

AFM images were used to explain the clear trend witnessed after electrochemical and salt spray testing and SEM analysis were used to further support the AFM findings. Surface roughness, particle size and average pore size derived from AFM image are given in Table 3. The AFM study detected the presence of pores widespread on the surface of $0 \% \mathrm{Mg}$ with typical pore size of $1.21 \mathrm{~nm}$ (Table 3). Particles were visible on all $\mathrm{Mg}\left(\mathrm{NO}_{3}\right)_{2}$ doped surface. The AFM images reveals that panels coated with low levels of 
magnesium appeared to be porous while $0.5 \%$ and $0.7 \% \mathrm{Mg}$ displayed higher packing levels (Fig. 8). The surface roughness and particle size derived form AFM images indicate that $0.5 \%$ and $0.7 \% \mathrm{Mg}$ have a more even surface and smaller particles (Table 3). For 1.0\% Mg showed agglomeration of particles with average particle size of $30 \pm 2 \mathrm{~nm}$.

\section{Fig. 8}

\section{Table 3}

SEM, used for inspection of the $0.5 \%$ and $0.7 \% \mathrm{Mg}$ coatings, revealed the presence of particulate matter at the surface prior to testing with few if any pores visible (Fig. 9). It is proposed that these particles are magnesium nitrate reservoirs within the coatings, which dissolve following electrolyte ingress and corrosion initiation to form insoluble magnesium precipitates capable of pore-blocking.

\section{Fig. 9}




\section{Conclusion}

The inclusion of an inhibitor in a sol-gel coating is essential in order to offer corrosion protection on aluminium alloys such AA2024-T3. Electrochemical (EIS, PDS) and accelerated exposure data (NSS) indicate that a methyltriethoxysilane coating containing $0.7 \%$ magnesium nitrate is capable of outperforming the standard hexavalent chromium surface treatment Alodine ${ }^{\mathrm{TM}} 1200$. Surface morphology studies (AFM and SEM) prior to testing displayed higher packing levels for $0.5 \%$ and $0.7 \% \mathrm{Mg}$ coatings with few if any pores visible. It is proposed that a suggested pore blocking mechanism occurs, whereby the $\mathrm{Mg}^{2+}$ ions present in the coating form insoluble precipitates, most likely $\mathrm{Mg}(\mathrm{OH})_{2}$ thereby preventing further electrolyte ingress. This result suggests inorganic inhibitors capable of forming insoluble precipitates may be suitable for inclusion in silane based sol-gels and acts as potential replacements for hexavalent chromium surface treatments on Aluminium alloys such as AA2024-T3. 


\section{References}

[1] J. Zhao, L. Xia, A. Sehgal, D. Lu, R.L. McCreery, G.S. Frankel, Surf. Coat. Technol.140 (2001) 51-57.

[2] T. L. Metroke, J. S. Gandhi, A. Apblett, Prog. Org. Coat. 50 (2004) 231-246.

[3] M. Khobaib, L. B. Reynolds, M. S. Donley, Surf. Coat. Technol. 140 (2001) 16-23.

[4] R.L. Twite, G.P. Bierwagen, Prog. Org. Coat. 33 (1998) 91.

[5] E. Almeida, L. Fedrizzi, T.C. Diamantinio, Surf. Coat. Technol. 105 (1998) 97-101.

[6] C. J. Brinker and G. W. Scherer, Sol-Gel Science: The Physics and Chemistry of Sol-Gel Processing, New York, 1990, Academic Press.

[7] M.L. Zheludkevich, I. M. Salvado, M. G. S. Ferreira, J. Mater. Chem. 15 (2005) 5099.

[8] N. Voevodin, C. Jeffcoate, L. Simon, M. Khobaib, M. Donley, Surf. Coat. Technol. 140 (2001) 29-34.

[9] K. Rose, Surface Coatings International Part B: Coat. Trans. 86 (2003) 247-328.

[10] M. L. Zheludkevich, R. Serra, M. F. Montemor, K. A. Yasakau, I. Miranda Salvado, M.G.S. Ferreira, Electrochimi. Acta 51 (2005) 208-217.

[11] N.N. Voevodin, N.T. Grebasch, W.S. Soto, F.E. Arnold, M.S. Donley, Surf. Coat. Technol. 140 (2001) 24-28.

[12] A. Pepe, M. Aparico, S. Cere, A. Duran, J. Non-Cryst. Solids 348 (2004) 162-171.

[13] V. Moutarlier, B. Neveu, M. P. Gigandet, Surf. Coat. Technol. 202 (2008) 2052-2058.

[14] K. Aramaki, Corros. Sci. 47 (2005) 1285-1298.

[15] H. Wang, R. Akid, Corros. Sci. 50 (2008) 1142-1148.

[16] S. Feliu Jr., R. Barajas, J.M. Bastidas, M. Morcillo, S. Feliu, Study of protection mechanisms of zinc rich paints by electrochemical impedance spectroscopy, in: J.R. Scully, D.C. Silverman, M.W. Kendig (Eds.), Electrochemical Impedance: Analysis and Interpretation, ASTM STP 1188, American Society for Testing and Materials, Philadelphia, 1993, pp. 438-449.

[17] D. Battocchi, A.M. Simões, D.E. Tallman, G.P. Bierwagen, Corros. Sci. 48 (2006) 1292-1306.

[18] D. Battocchi, A.M. Simoes, D.E. Tallman, G.P. Bierwagen, Corros. Sci. 48 (2006) 2226-2240.

[19] A. M. Simoes, D. Battocchi, D. E. Tallman and G. P. Bierwagen, Corros. Sci. 49 (2007) 3838-3849.

[20] M.E. Nanna, G.P. Bierwagen, JCT Res. 1 (2004) 69-81.

[21] A.N. Khramov, N.N. Voevodin, V.N. Balbyshev, R.A. Mantz, Thin Solid Films 483 (2005) 191-196.

[22] A. J. Bard, L.R. Faulkner, Electrochemical Methods. Fundamentals and Applications, John Wiley and Sons, New York, 1980, p. 105.

[23] M. L. Zheludkevich, R. Serra, M. F. Montemor, M. Ferreira, Electrochem. Commun. 7 (2005) 836840.

[24] V. Palanivel, Danquing Zhu, W.J. van Ooij, Presentation at The Workshop on Nanoscale Approaches to Multifunctional Coatings, Keystone, CO, August 12-16, 2002. 
[25] M.L. Zheludkevich, R. Serra, M.F. Montemor, I.M. Miranda Salvado, M.G.S. Ferreira, Surf. Coat. Technol., 200 (2006) 3084.

[26] P.I. Dolin, B.V. Ershler, Acta Physicochem. URSS 13 (1940) 747

[27] J.E.B. Randles, Discuss. Faraday Soc. 1 (1947) 11.

[28] C. Corfias, N. Pebere, C. Lacabanne, Corros. Sci. 41 (1999) 1539-1555.

[29] C. Blanc, B. Lavelle, G. Mankowski, Corros. Sci. 39 (1997) 495-510.

[30] N. Dimitrov, J. A, Mann, K. Sieradzki, J. Electrochem . Soc. 149 (1999) 98.

[31] K. A. Yasakau, M. L. Zheludkevich, S. V. Lamaka, M. G. S. Ferreira, J. Phys. Chem. B 110 (2006) 5515.

[32] M. Kendig, S. Jeanjaquet, R. Addison, J. Waldrop, Surf. Coat.Technol. 140 (2001) 58-66.

[33] M. Stern, A.L. Geary, J Electrochem Soc 104 (1957) 56-63.

[34] V. Palanivel, Y. Huangb, W. J. van Ooij, Prog. Org. Coat. 53 (2005) 153-168.

[35] D. Battocchi, A. M. Simoes, D. E. Tallman, G. P. Bierwagen, Corros. Sci. 48 (2006) 1292-1306. 


\section{Tables Caption}

Table 1: Parameters of the sol-gel film systems with various percentage of MgN doped, obtained from fitting of the experimental impedance spectra with different equivalent circuits

\begin{tabular}{|c|c|c|c|c|c|c|c|c|c|c|c|c|}
\hline Sol gel Coating & \multicolumn{2}{|c|}{ 0\% Mg } & \multicolumn{2}{|c|}{$0.1 \% \mathrm{Mg}$} & \multicolumn{2}{|c|}{$0.3 \% \mathrm{Mg}$} & \multicolumn{2}{|c|}{$0.5 \% \mathrm{Mg}$} & \multicolumn{2}{|c|}{$0.7 \% \mathrm{Mg}$} & \multicolumn{2}{|c|}{$1.0 \% \mathrm{Mg}$} \\
\hline $\begin{array}{l}\text { Immersion time } \\
\text { (Hrs) }\end{array}$ & 0 & 72 & 0 & 72 & 0 & 72 & 0 & 72 & 0 & 72 & 0 & 72 \\
\hline $\mathrm{R}_{\mathrm{sol}}\left(\Omega \mathrm{cm}^{2}\right)$ & 2.08 & 5.25 & 0.34 & 2.32 & 0.65 & 0.50 & 0.93 & 0.57 & 0.89 & 1.33 & 2.41 & -4.46 \\
\hline $\begin{array}{l}\mathrm{C}_{\text {coat }}{ }^{-T} \\
\left(\mathrm{x} 10^{-7} \mathrm{~F} . \mathrm{cm}^{-2}\right)\end{array}$ & 2.17 & 2.57 & 0.46 & 1.94 & 0.85 & 1.33 & 0.45 & 0.99 & 0.58 & 0.70 & 0.95 & 1.98 \\
\hline $\mathrm{C}_{\text {coat }}-\mathrm{P}$ & 0.99 & 0.99 & 0.97 & 0.88 & 0.95 & 0.91 & 0.96 & 0.95 & 0.90 & 0.85 & 0.92 & 0.91 \\
\hline $\begin{array}{l}\mathrm{R}_{\text {coat }} \\
\left(\mathrm{x} 10^{6} \Omega . \mathrm{cm}^{2}\right)\end{array}$ & 0.66 & 0.05 & 3.42 & 0.08 & 7.41 & 0.27 & 4.62 & 1.78 & 1.94 & 1.37 & 3.64 & 0.01 \\
\hline $\begin{array}{l}\mathrm{C}_{\mathrm{dl}}-\mathrm{T} \\
\left(\mathrm{x} 10^{-5} \mathrm{~F} \cdot \mathrm{cm}^{-2}\right)\end{array}$ & - & 1.16 & - & 1.12 & - & 0.14 & - & 0.44 & - & 0.59 & - & 0.12 \\
\hline $\mathrm{C}_{\mathrm{dl}}-\mathrm{P}$ & - & 0.99 & - & 0.97 & - & 0.73 & - & 0.74 & - & 0.89 & - & 0.74 \\
\hline $\begin{array}{l}\mathrm{R}_{\text {int }} \\
\left(\mathrm{x} 10^{6} \Omega \cdot \mathrm{cm}^{2}\right)\end{array}$ & - & 0.05 & - & 5.75 & - & 1.50 & - & 4.43 & - & 1.18 & - & 0.05 \\
\hline
\end{tabular}


Table 2: Corrosion Parameters estimated from Potentiodynamic Scan for bare, Alodine ${ }^{\mathrm{TM}} 1200$ treated and sol-gel coated AA2024-T3 alloy.

\begin{tabular}{|lllll|ll|}
\hline Coating & $\mathrm{I}_{\text {corr }}\left(\mathrm{A} . \mathrm{cm}^{-2}\right)$ & $\mathrm{E}_{\text {corr }}(\mathrm{V})$ & $\beta_{\mathrm{a}}\left(\mathrm{V} \cdot \mathrm{dec}^{-1}\right)$ & $\beta_{\mathrm{c}}\left(\mathrm{V} . \mathrm{dec}^{-1}\right)$ & $\mathrm{R}_{\mathrm{p}}\left(\Omega . \mathrm{cm}^{2}\right)$ \\
\hline Bare AA 2024 & $4.41 \times 10^{-6}$ & -0.495 & 0.009 & 0.078 & $9.86 \times 10^{2}$ \\
\hline Alodine & $1.05 \times 10^{-8}$ & -0.418 & 0.015 & 0.050 & $9.20 \times 10^{5}$ \\
\hline MTEOS $+0 \% \mathrm{Mg}$ & $3.74 \times 10^{-6}$ & -0.485 & 0.011 & 0.061 & $5.70 \times 10^{3}$ \\
\hline$+0.1 \% \mathrm{Mg}$ & $4.99 \times 10^{-9}$ & -0.511 & 0.013 & 0.043 & $1.70 \times 10^{5}$ \\
\hline$+0.3 \% \mathrm{Mg}$ & $1.02 \times 10^{-10}$ & -0.507 & 0.025 & 0.027 & $2.40 \times 10^{9}$ \\
\hline$+0.5 \% \mathrm{Mg}$ & $1.37 \times 10^{-10}$ & -0.485 & 0.026 & 0.027 & $4.31 \times 10^{9}$ \\
\hline$+0.7 \% \mathrm{Mg}$ & $2.25 \times 10^{-11}$ & -0.456 & 0.014 & 0.017 & $1.70 \times 10^{9}$ \\
\hline$+1.0 \% \mathrm{Mg}$ & $2.10 \times 10^{-8}$ & -0.497 & 0.009 & 0.041 & $2.60 \times 10^{5}$ \\
\hline
\end{tabular}


Table 3: Surface roughness (rms), particle size and average pore size of sol-gel coated AA2024-T3 alloy.

\begin{tabular}{|rccc|}
\hline Coating & $\begin{array}{c}\text { Surface roughness } \\
(\mathrm{nm})\end{array}$ & $\begin{array}{c}\text { Particle size } \\
(\mathrm{nm})\end{array}$ & $\begin{array}{c}\text { Avg pore size } \\
(\mathrm{nm})\end{array}$ \\
\hline MTEOS $+0 \% \mathrm{Mg}$ & 4.01 & - & $1.50 \pm 0.2$ \\
\hline$+0.1 \% \mathrm{Mg}$ & 2.62 & $1.5 \pm 0.5$ & $0.75 \pm 0.5$ \\
\hline$+0.3 \% \mathrm{Mg}$ & 1.84 & $10 \pm 2.0$ & $0.4 \pm 0.5$ \\
\hline$+0.5 \% \mathrm{Mg}$ & 1.25 & $6 \pm 1.0$ & - \\
\hline$+0.7 \% \mathrm{Mg}$ & 0.51 & $4 \pm 1.0$ & - \\
\hline$+1.0 \% \mathrm{Mg}$ & 3.07 & $30 \pm 2.0$ & $1.21 \pm 0.5$ \\
\hline
\end{tabular}




\section{Figure List:}

Fig. 1: Plot of Log $|\mathrm{Z}|_{0.1 \mathrm{~Hz}}$ vs Time for sol-gel coatings immersed in electrolyte (Harrison's Solution) for up to 72 hours

Fig. 2: Impedance spectra of the AA2024 coated with sol-gel films doped with different concentration of magnesium nitrate taken after (a) $0 \mathrm{hr}$ and (b) $72 \mathrm{hrs}$ exposed to Harrison's solution.

Fig 3: Equivalent circuit models used for numerical fitting of the EIS data (a) $0 \mathrm{hrs}$ (b) after $24 \mathrm{hrs}$.

Fig. 4: Time profile of sol-gel coating (a) capacitance, (b) coating resistance, during immersion in electrolyte (Harrison's Solution)

Figure 5: Potentiodynamic polarisation curves of sol-gel coating immersed in electrolyte (Harrison's Solution)

Fig. 6: Potentiodynamic scan curves comparing selected sol-gel and Alodine ${ }^{\mathrm{TM}} 1200$ coated to Bare AA2024-T3 alloy

Fig 7: Salt spray test results (1) Bare AA2024 after 24hrs exposure (2) MTEOS coating after $120 \mathrm{hrs}$ exposure and (3) $0.1 \% \mathrm{Mg}$, (4) $0.3 \% \mathrm{Mg}$, (5) $0.5 \% \mathrm{Mg}$, (6) $0.7 \%$, (7) $1.0 \% \mathrm{Mg},(8)$ Alodine ${ }^{\mathrm{TM}} 1200$ coating system after 1 week of exposure

Figure 8: AFM images of sol-gel coatings (a) $0 \% \mathrm{Mg}$, (b) $0.1 \% \mathrm{Mg}$, (c) $0.3 \% \mathrm{Mg}$ (d) $0.5 \% \mathrm{Mg}$, (e) $0.7 \% \mathrm{Mg}$, (f) $1.0 \% \mathrm{Mg}$

Figure 9: SEM images of sol-gel coatings (a) $0.5 \% \mathrm{Mg}$ (b) $0.7 \% \mathrm{Mg}$ 
Fig 1

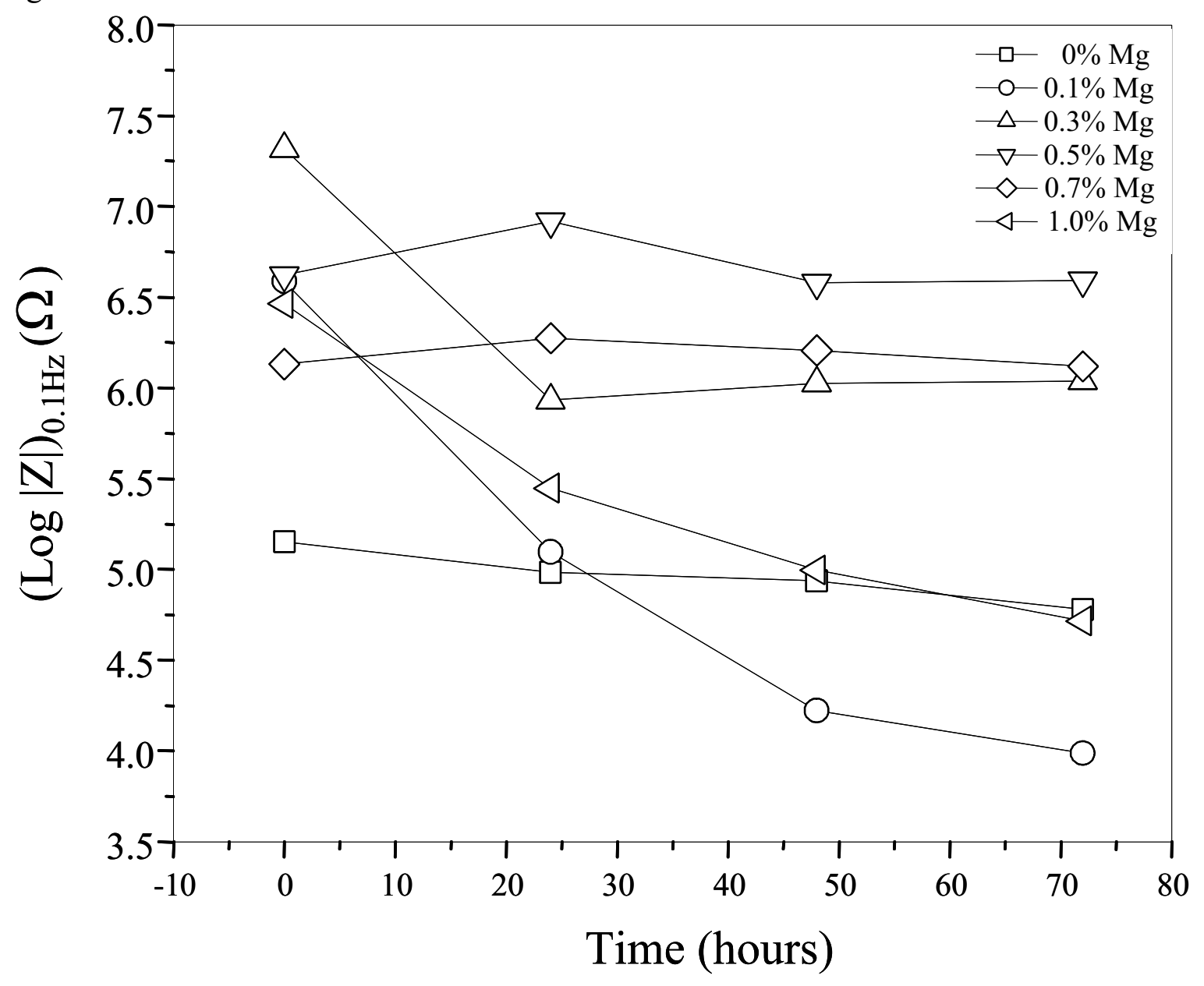


Fig 2a

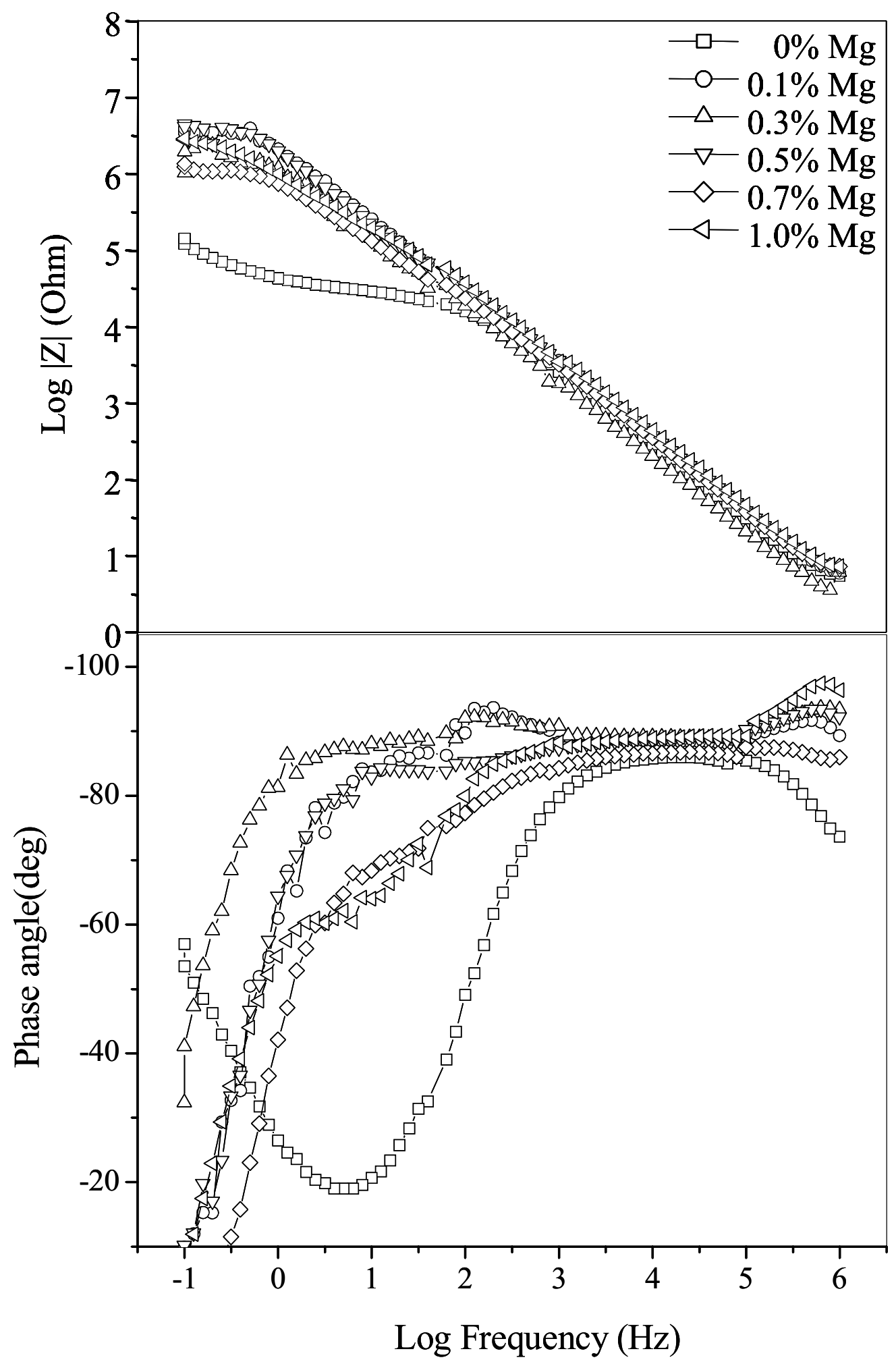


Fig 2b

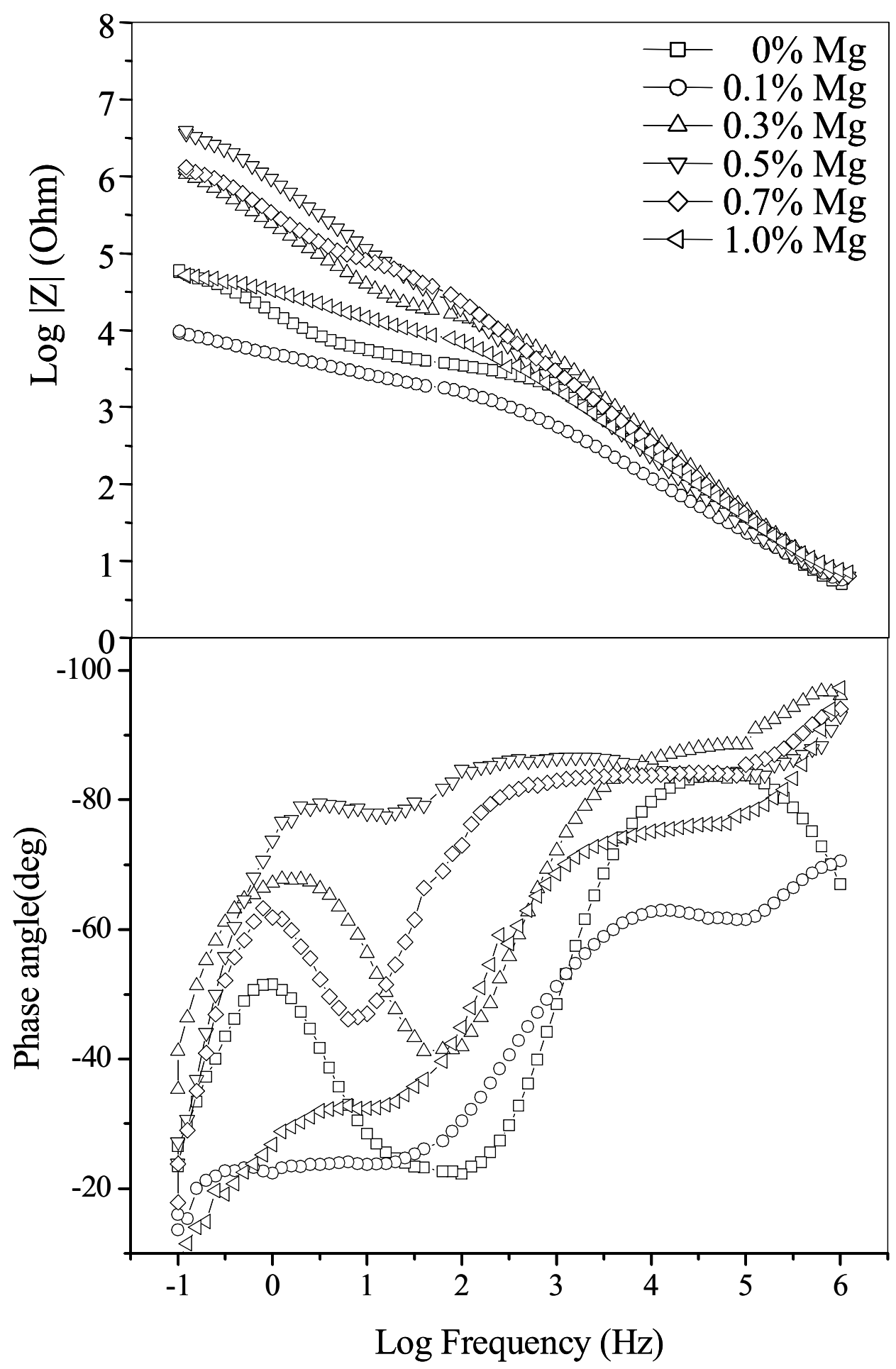


Fig 3 (a)\&(b)

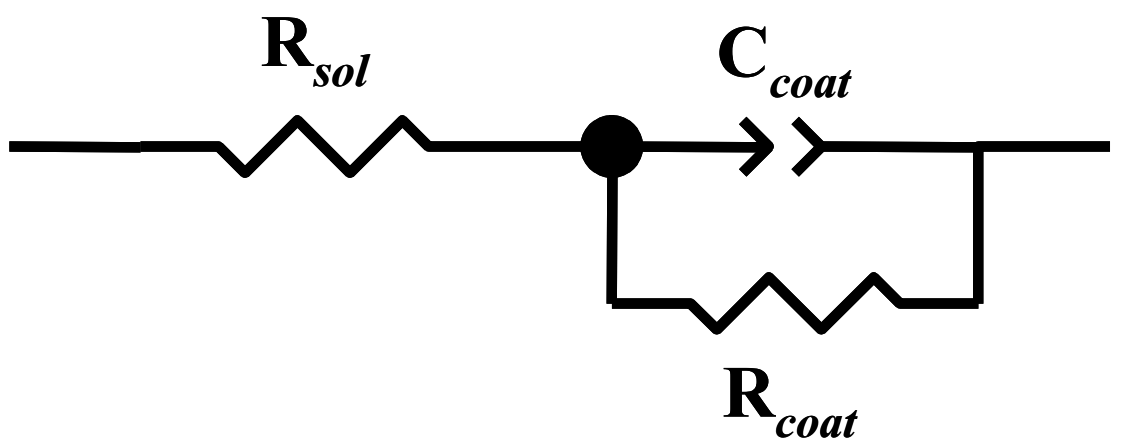

(a)

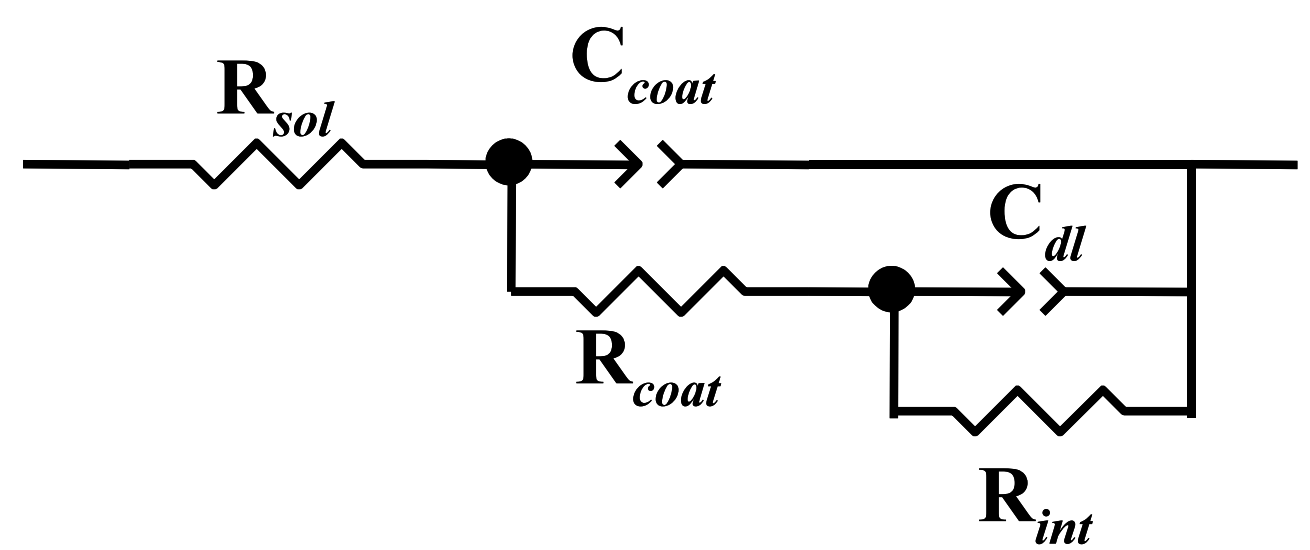

(b) 
Fig 4 (a)

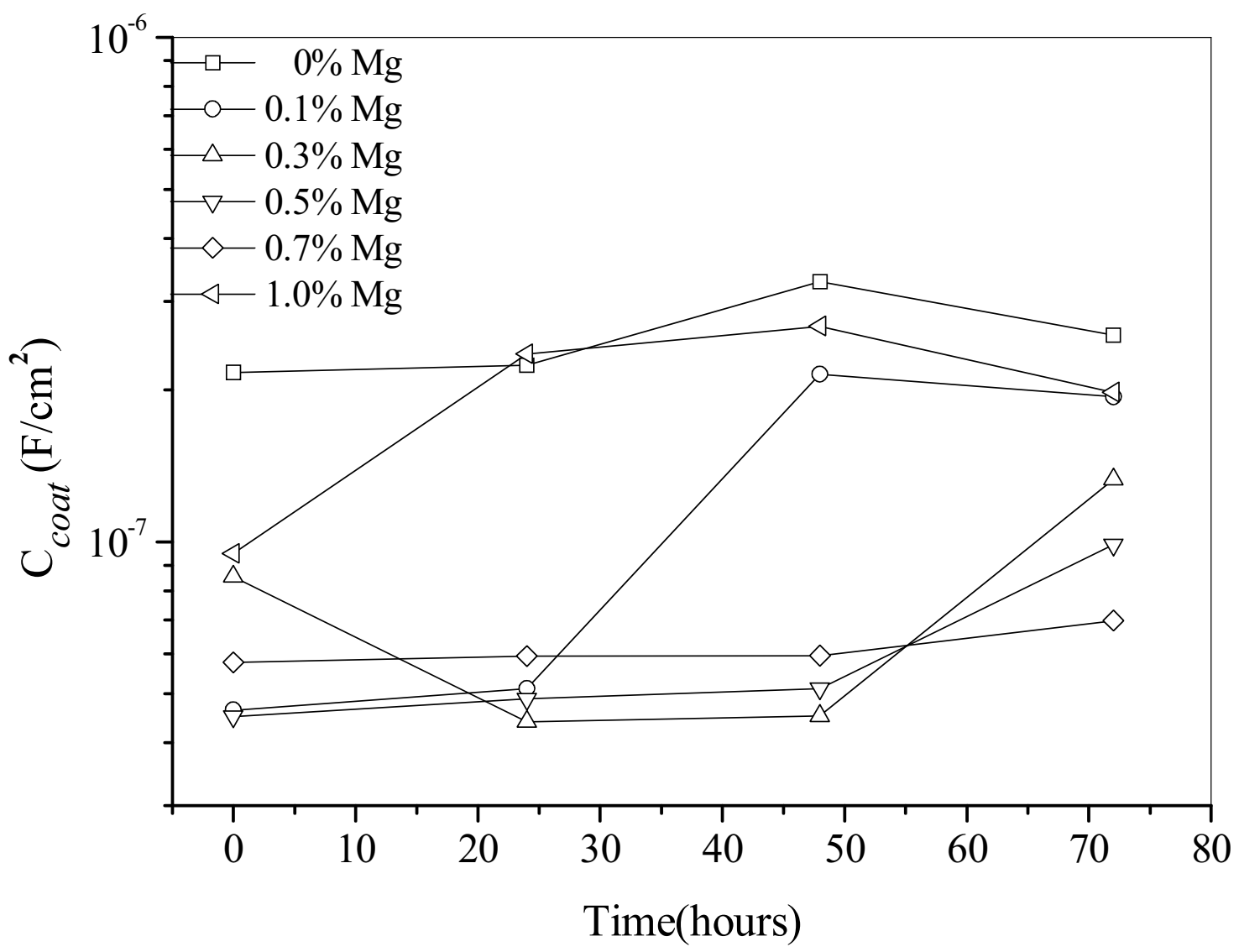


Fig 4 (b)

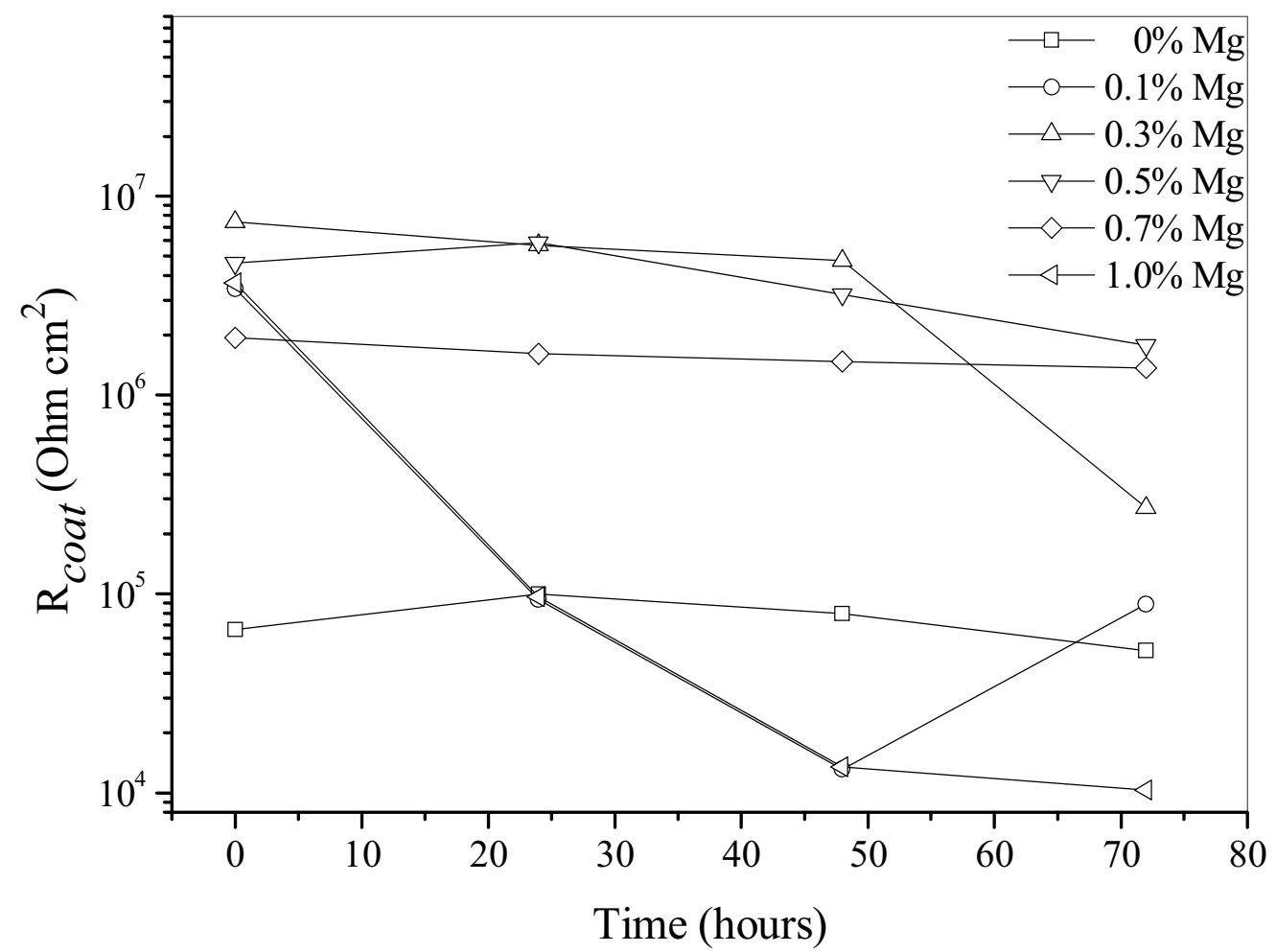


Fig 5

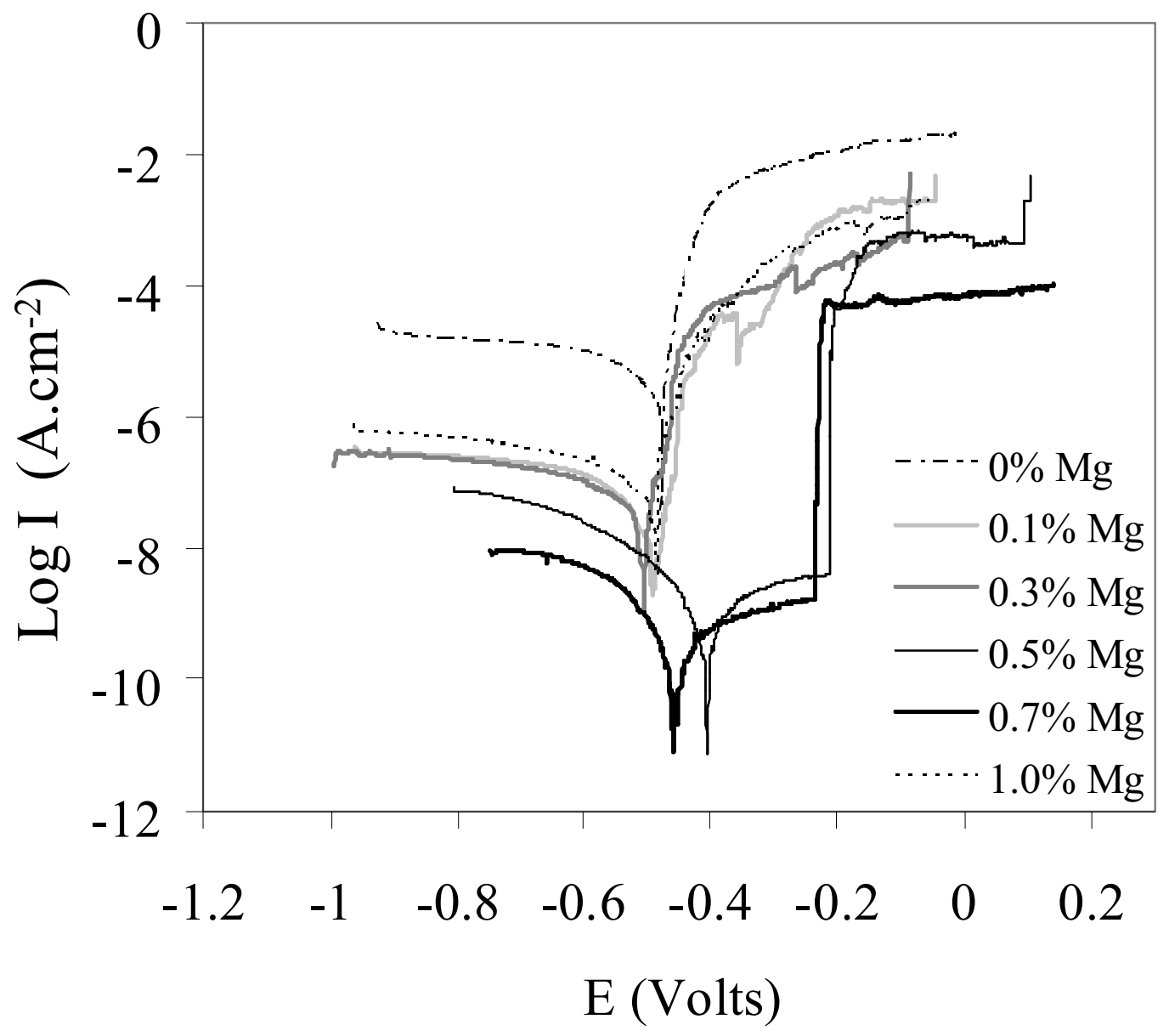


Fig 6

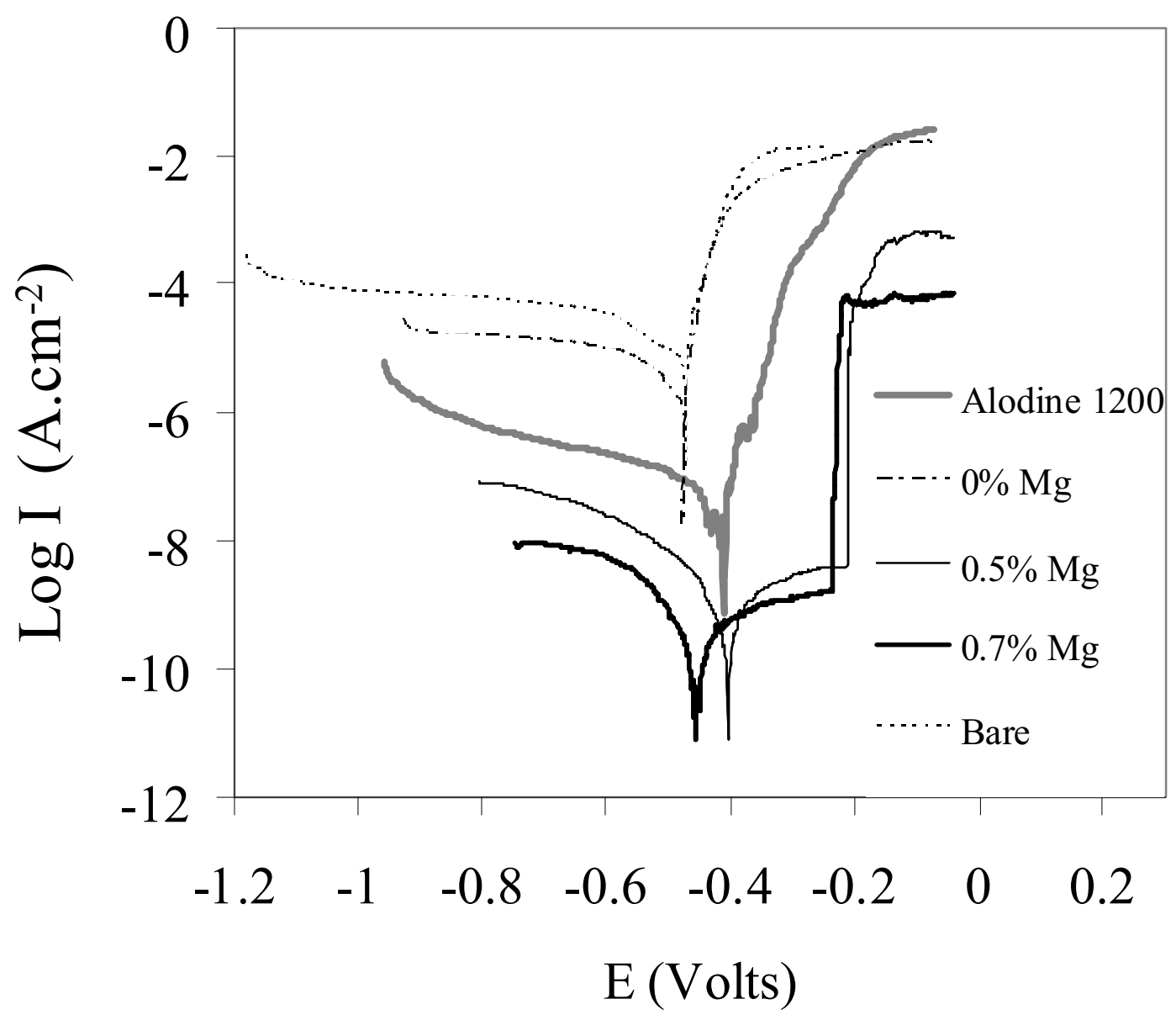


Fig 7

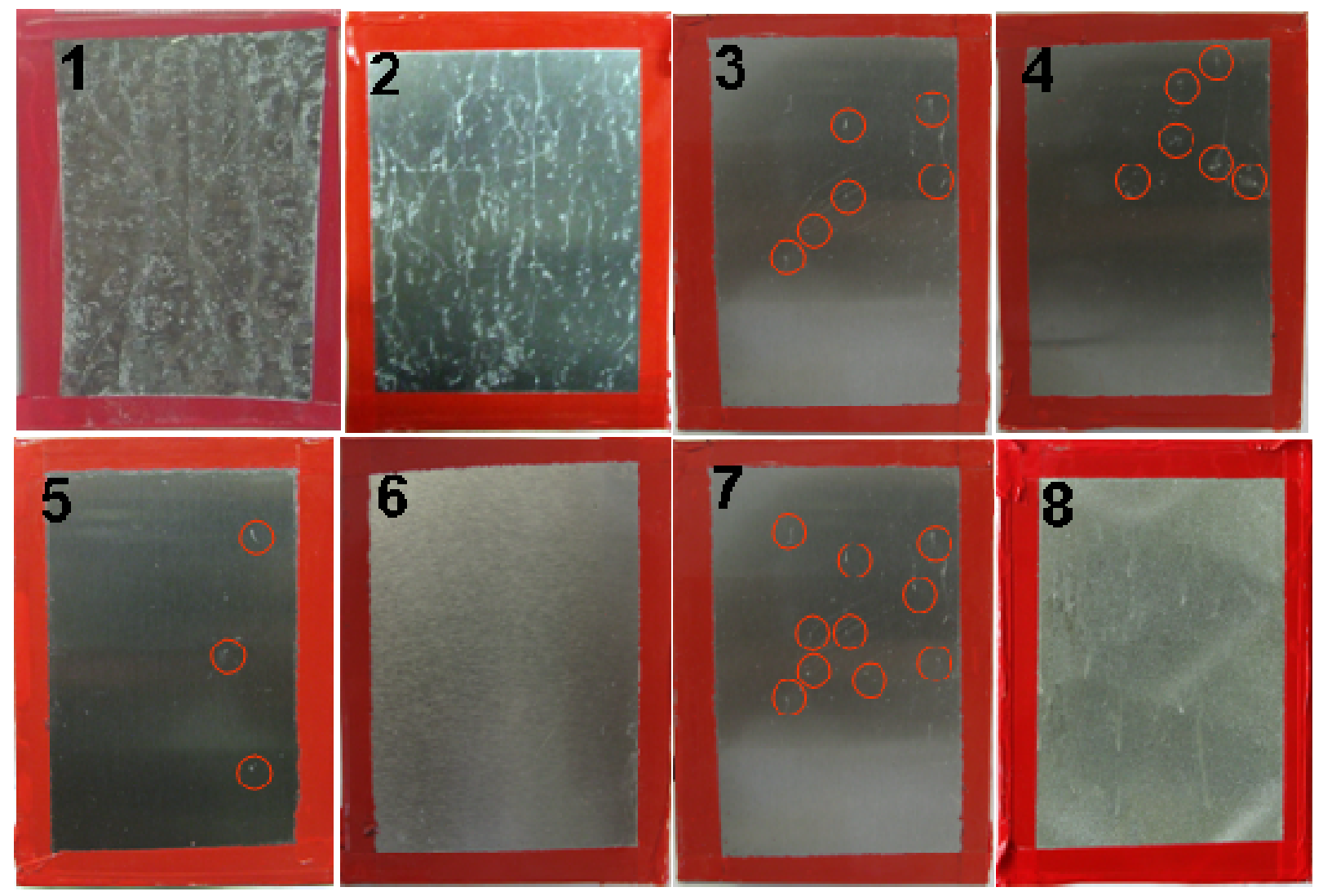


Fig. 8
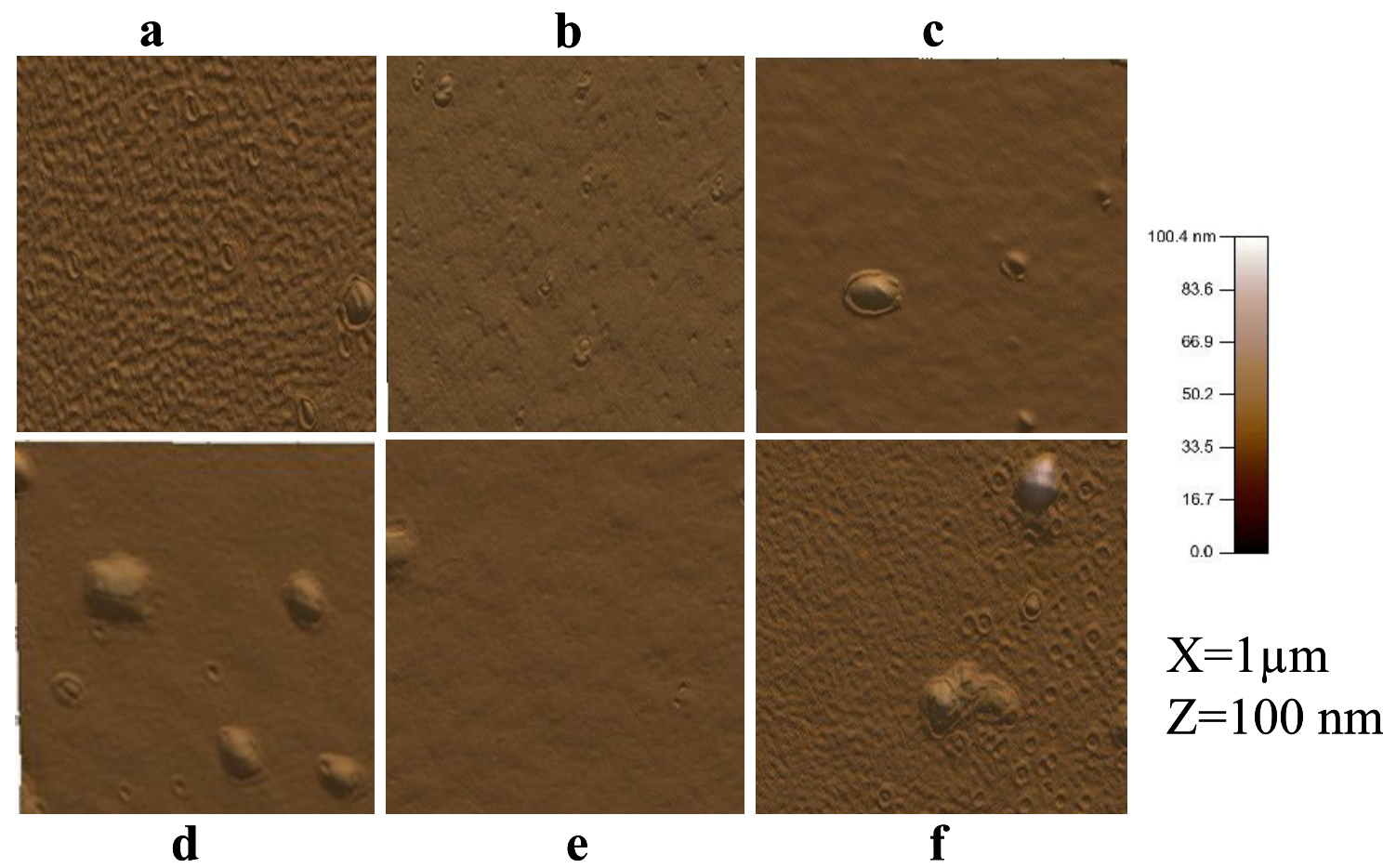

d

e 
Fig 9

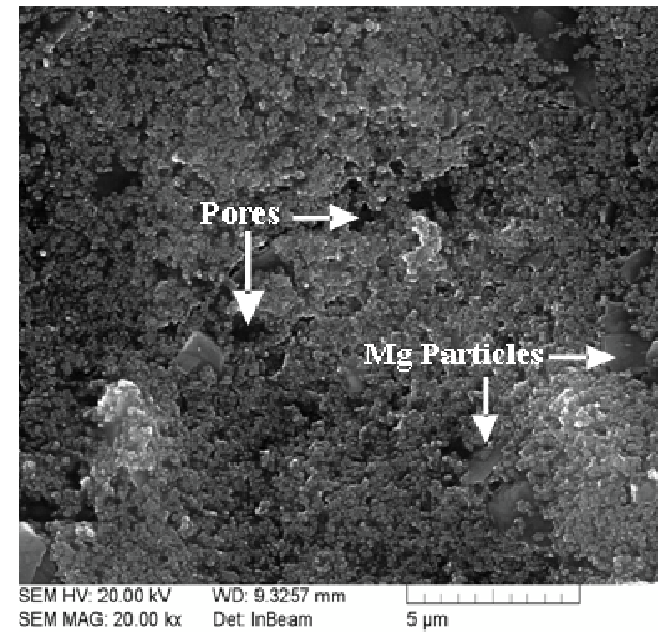

(a)

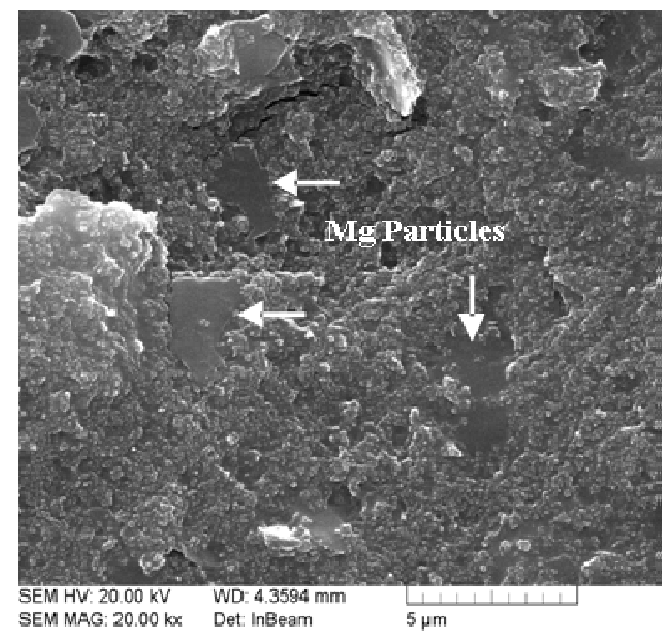

(b) 